\title{
Migration policy reforms in the context of economic and political crises: the case of Belgium
}

\author{
Sonia Gsir ${ }^{a}$, Jean-Michel Lafleur ${ }^{a}$ and Mikolaj Stanek ${ }^{b}$ \\ ${ }^{a}$ CEDEM, University of Liège, Liège, Belgium; ${ }^{b}$ Centre of Social Studies, University of Coimbra, Coimbra, \\ Portugal
}

\begin{abstract}
A body of literature has examined the role of 'crises' on policymaking. Yet, we observe that endogenous or exogenous events called 'crisis-events' are often randomly chosen as sweeping explanations for reforms in migration and integration policy. Thus, we attempt to find answers for the question of how the latest financial and economic crisis affected policy-making in the area of migration and integration. We apply a combination of interestbased and ideas-based theories to the case of Belgium in order to question the role of crises in policy reforms in the field of migration and integration. Multiple political and economic crises have affected the country since 2007 . Examining these crises and immigration politics we argue that electoral competition both between and within the Francophone and Flemish party systems continues to be the main driver of migration and integration policy reform. Yet, we also discover a cumulative effect of economic and political crises: while the intention of restricting immigration has remained largely unchanged over the years, the policy instruments employed to reach this objective have changed with the political and economic crises.
\end{abstract}

\section{KEYWORDS}

Economic crisis; migration policy; integration; reforms; federalism; Belgium

\section{Introduction}

Crises are generally considered as 'turning points' (Alink, Boin, and T'Hart 2001, 300) and the global financial crisis of 2008 was undoubtedly a crucial one in Europe. The crisis triggered many reforms in economic and financial policies all over Europe but its effect on migration policies is a research topic that has received surprisingly little attention. Part of the reason for this may be that, based on the observation of previous crises, the assumption is that economic crises are strictly considered as opportunities to implement restrictive immigration policies. For instance, the Great Depression of the 1920s and the Oil Crises of the 1970s were both occasions during which states implemented stronger barriers to immigration as a response to deteriorating labour market conditions. In the case of the current economic crisis, scholars have also noted that two kinds of impact have affected immigrants primarily (Papademetriou, Sumption, and Somerville 2009; Papademetriou and Terrazas 2009; Cerna 2010). Firstly, the economic crisis has tightened regulations on migration control as well as integration policies. Secondly, the crisis has greatly 
worsened labour market conditions which - together with rising xenophobia and protectionism in destination countries - has contributed to growing unemployment, a decrease in migration flow, as well as waves of return migration to certain countries of origin.

In this article, we intend to question the simplistic link between economic crises and the adoption of restrictive immigration policies. More precisely, we hypothesise that narratives built by policy-makers to justify reforms in the context of economic crisis may obscure broader social, economic or political variables that are equally or more relevant in understanding policy reform processes. Analysing the case of Belgium, this article explains in particular how political and economic crises conflate and create pressure for limited policy reforms while leaving policy objectives untouched.

Studying small open economies like Belgium is particularly relevant in understanding the effect of crises on policy reforms. According to the political economy literature, such economies are particularly vulnerable in the global economy since they are 'forced to expose themselves to the chill winds of world markets and global competition given the small size of their domestic markets' (Obinger et al. 2010, 6). The dependence of these economies on the world market thus makes them particularly exposed to global crises like the 2008 financial and economic crisis - but also potentially more adaptable and reactive to changing socio-economic conditions. Belgium's federal structure and its ongoing ethno-linguistic conflict, however, significantly complicate the process of policy reform. Belgium has two party systems - Flemish and Francophone - and different parties compete within each political system exclusively for the votes of citizens belonging to their own ethno-linguistic community. ${ }^{1}$ Over the years, these two party systems have revealed strong differences in the ideological preferences of Belgian citizens: Flemish voters prefer centre-right and nationalist parties, while centre-left parties dominate the Francophone party system. The devolution process in Belgium has granted Regions with important prerogatives in the field of integration (with the exception of nationality and voting rights) but most of the immigration policies are still designed at the national level.

Immigration and integration policies have undergone profound transformations since the beginning of the economic crisis in Belgium. Yet, we posit that policy objectives have remained largely untouched since the 1970s: that is, the goal is to restrict immigration. For this reason, we argue that the recession merely constituted an opportunity to adjust existing policy instruments and to adopt new ones to reach those same goals. Most importantly, we show below that the economic crisis in Belgium only partly explains the policy reforms that have been implemented. In 2007 and in 2010-2011, Belgium also went through two of the most severe political crises of its history, leaving the country without a government for several months. These political crises revealed major political divergences between the Flemish and Francophone parties, which eventually led to the formation of a government in 2011 that excluded the country's biggest political party (the National Flemish Alliance, hereafter the N-VA). This government, however, implemented the migration policy promoted by the oppositional N-VA in order to appeal to voters of the party.

In this article, our objective is twofold: first, to show how the context of double (economic and political) crises affects policy-making in the field of migration and integration and second, to examine a possible combined effects of the different crises. To achieve this goal, and in line with George and Bennett (2005), we use a 'process-tracing 
method' in order to identify the key mechanisms and interactions that reveal the causal process between the crises and the policy reforms. In the first section, we articulate interest-based and ideas-based approaches to policy-making and examine the broader literature on policy-making in times of crisis. As part of this analysis, we posit that while political competition remains the main driver of policy reforms, crises may alter the goals of those policies, alter the settings of policy instruments to reach those goals and even trigger the adoption of new policy instruments.

Second, we focus on the transformation of Belgium's immigration and integration policies in the context of the political and economic crises. We show that this led political parties to mobilise new frames in debates on migration and integration policies. More precisely, we show how three trends have clearly emerged from the diversity of reforms adopted in the last decade: (1) selectivity towards would-be migrants has increased, (2) policies are becoming more coercive as sanctions are made part of policies and (3) social policy has turned into a tool for migration control. Our analysis discusses numerous policy reforms in the 2007-2014 period, with a particular focus on three policies that affected most strongly immigrants themselves but that also generated the greatest number of political debates: (1) the 2011 law on family reunification, (2) the removal of residence permits from EU citizens using welfare and (3) the 2012 reform of nationality law. Using existing literature, parliamentary archives and sources from the press, we show how policy instruments rather than the overall objectives of migration and integration policies have been altered by the crises. Third, we conclude with a discussion on the contribution of the Belgian case study to the understanding of migration policy reforms in the context of crises. This article allows in particular to highlight the combined effects of multiple crises. In a context of the increased politicisation of migration and asylum issues in Europe since 2015, we argue that combining interest-based and ideasbased approaches to policy-making like we do could also be useful to analyse other European states facing economic, political and, humanitarian crises at the same time.

\section{Theoretical insights on crises and migration policy reforms}

At the outset of this article, we posited that in the aftermath of the global financial crisis, states have implemented protective measures and restrictive immigration policies. For authors such as Kuptsch $(2012,19)$, migration policy reforms in receiving countries during the global economic crisis consisted mostly of four types of measures: (1) making immigration more difficult, (2) protecting native workers, (3) employing more measures to increase return of immigrants and (4) clamping down on irregular migrants. Yet, while these changes are concomitant with the economic crisis, the question of causality remains. Has the economic crisis triggered the reforms or would they have happened anyway? In other words, how can we avoid endogenous or exogenous events being randomly chosen as sweeping explanations for migration and integration policy reforms?

Scholars have struggled for several decades both to define crises and to theorise their role in policy-making (Hall and Taylor 1996; Legro 2000). A point of departure is to determine whether our understanding of what constitutes a crisis has evolved due to the magnitude and length of the current economic and financial crisis. Nohrsted and Weible $(2010,3)$ have made a contribution to this debate, noting that crises are usually considered as 'periods of disorder in the seemingly normal development of a system and widespread 
questioning or discrediting of established policies, practices, and institutions'. The nature of a crisis may, however, differ according to certain variables. First, a crisis may be caused by either an internal or an external shock. While this basic 'external-internal' distinction may appear to be of limited use at first sight, it refers to the geographic scale at which stimuli for policy reforms occur, which, in turn, affects the ability and autonomy of policy-makers to react. This relates to the second axis of variation, which is the intensity of a crisis: not all crises - even when they are described as global (e.g. the 2008 financial and economic crisis) - are equally severe nor do they equally affect all states. However, there is still no agreement in the literature on possible correlations between the scale of a crisis and the importance of the reforms adopted in reaction to it. Third, crises also vary in the responses they provoke, according to the existing prerogatives of policymakers and most importantly, according to their subjective interpretation of what constitutes an adequate response to the crisis. As observed with the reaction shown by several EU member states to the 2008 financial and economic crisis, the same external crisis with broadly similar effects on their socio-economic situations may lead two states to adopt different reforms in the same policy area or to even adopt reforms in different policy areas.

As mentioned previously, the specificity of the Belgian case study is that over the past decade, the country has gone through both internal and external crises: the financial and economic crisis represented a shock that was external to Belgian policy-makers, while the political crises were very much the result of internal strife between political parties defending the interests of different ethno-linguistic groups. For this reason, studying the Belgian case constitutes an ideal opportunity to identify both the differentiated effects of each type of crisis and the specific effects of their combination on policy-makers.

Because ethno-linguistic tensions between Francophone and Flemish political parties have been a defining feature of Belgian politics for several decades, we believe that an interest-based approach to migration policy reform has historically been the most appropriate choice to understand the evolution of Belgium's migration and integration policies. Following the pluralist model of migration policy-making, states act according to the interests defined by organised groups (e.g. trade unions, lobbies, political parties) guided by economic, political or humanitarian motives (Money 1999; Watts 2002). Following this approach, '[i]mmigration policy is the outcome of a political process through which competing interests interact within bureaucratic, legislative, judicial, and public arenas to construct and implement policies that encourage, discourage, or otherwise regulate the flows of immigrants' (Massey 1999, 307). Freeman's focus on the role of electoral competition in explaining policy reforms is of interest in our case. For Freeman, migration policies must be studied by observing voters, interest groups and their relations with the state: ' $t$ ]he optimal immigration policy [...] is that preferred by the median voters where voters are utility-maximizers with complete information' (Freeman 1995, 883).

In spite of criticism of the neglect shown by this approach of the symbolic dimension of immigration (Boswell 2007), the role of institutions and ideologies (Hollifield 2000) and the role of judicial processes (Joppke 1998), Freeman's interest-based model seems particularly relevant to us because it is political competition that has framed Belgian migration and integration policies at two levels. First, within each political system, political parties have used migration and integration issues to differentiate themselves and to gain electoral support. Second, at the Federal level where migration policy and parts of the 
integration policy are designed, the Flemish and Francophone political systems compete with one another as parties are trying to impose their views on national policies. Because of the different ideological orientations between the Flemish and Francophone political systems and because these parties only respond to voters who belong to their own ethno-linguistic group, debates on migration and integration issues often become highly salient before coalition governments at the Federal level can reach a compromise (see, for instance, Jacobs 1999 on the debate on the enfranchisement of foreigners in local elections).

Even though an interest-based analysis aids our understanding of Belgian migration and integration policy in the context of devolution, it does not explain satisfactorily why policies have become increasingly selective and coercive in the context of the political and economic crises of the past decade. It is for this reason that we combine the interestbased perspective with ideas-based theories that stress the influence of ideas and perceptions on policy reforms. According to Muller and Surel (1998), public policies are not aimed at 'solving problems' but rather at constructing a new representation of the problem that puts in place the necessary socio-economic conditions for the problem to be resolved by public authorities. This entails a different vision of policy-making, which involves three central variables that are susceptible to being reformed in times of crisis: 'the overarching goals that guide policy in a particular field, the techniques or policy instruments used to attain those goals, and the precise settings of these instruments' (Hall 1993, 278).

As we will show in the next section, even though migration had been considered as a 'problem' by policy-makers previously, the recent economic crisis have allowed migration and integration reforms to be framed in a context of decreasing public finances and 'scarce resources'. Those frames have enabled policy-makers to adjust existing policy instruments and to adopt new ones, while leaving untouched the overall policy objective of further restricting immigration.

\section{The evolution of Belgium's migration and integration policies in the context of double crisis}

\subsection{Pre-crisis immigration and integration policies in Belgium}

Similarly to other European countries, Belgium started an active immigration policy after World War II by signing bilateral agreements with Southern European governments and later with non-European countries. Following the oil crisis and the subsequent economic recession of the 1970s, the Belgian government stopped actively recruiting low-skilled workers in 1974. Nevertheless, a limited work migration continued and, most importantly, family migration became the privileged avenue for foreigners wishing to move to Belgium. Parliament consequently adopted the law of 15 December 1980, regulating access to the territory as well as the sojourn, the settlement and the removal of foreigners (also known as the Aliens Law), with the aim of stopping new immigration and fostering the integration of those already present in the territory (Rea 2006, 193). In the mid-1980s, Belgium experienced renewed migration from Eastern Europe, Africa and Asia (see Bousetta, Gsir, and Jacobs 2007, 34; Martiniello et al. 2010) and in the 1990s, the number of applications for asylum increased rapidly, creating a growing undocumented population 
in the process. During the 2000s, with the same recurring objective of limiting new immigration, the Belgian government imposed transitional measures to limit access to its labour market for new EU citizens whose countries had joined the EU in 2004, 2007 or 2013 (with the exception of Maltese and Cypriot citizens). Nonetheless, Belgium still experienced a strong increase in inflows of EU migrants proceeding from Central and Eastern European member states (Table 1).

In the period between the Oil Crises of the 1970s and the 2008 economic crisis, immigration and integration policy reforms were continuously readjusting to changing socioeconomic conditions and the changing institutional context, characterised internally by regional devolution and externally by the process of EU integration. However, Belgium never really questioned its 1970 s' zero immigration doctrine. In line with interest-based approaches to migration and integration policy-making, scholars have noted that the presence of a strong extreme-right party - such as the Flemish Vlaams Blok (later called the Vlaams Belang) - explains the country's restrictive approaches to migration (Koopmans, Michalowski, and Waibel 2012). As a result of the electoral success of this party, migration and integration are becoming central topics that other parties also have to pick up on during electoral campaigns (Coffé 2005; Adam and Torrekens 2015). This explains the persisting restrictive approach in immigration policies adopted at the Federal level, where the pressure on the Flemish parties to appear strict on migration meets with the Francophone parties' traditionally less restrictive approaches on the issue. Most importantly, it explains the diverging paths of Flanders' and Wallonia's integration policies during this period.

Following the constitutional process of regional devolution, Belgium turned progressively into a federal state with prerogatives in the field of integration being transferred to subnational entities. Integration policies in the country's two biggest regions - Flanders and Wallonia - were originally based on two decrees, respectively the decree on the integration of foreigners or persons of foreign origin, signed in 1996 by the Walloon government, and the minorities decree, signed by the Flemish government in $1998 .^{2}$ The Flemish policy was initially based on the idea of the recognition of groups, even though particular ethnic groups were not formally recognised. In addition to this multicultural approach, a more assimilationist approach was initiated at the end of the 1990s and further developed

Table 1. Foreign regular residents in Belgium 1970-2013 (by nationality).

\begin{tabular}{|c|c|c|c|c|c|c|}
\hline & 1970 & 1981 & 1991 & 2000 & 2010 & 2013 \\
\hline Germany & 22.956 & 27.619 & 27.924 & 34.328 & 39.421 & 39.745 \\
\hline France & 86.658 & 103.512 & 93.363 & 107.240 & 140.227 & 153.413 \\
\hline The Netherlands & 61.261 & 66.233 & 65.294 & 85.763 & 133.536 & 143.977 \\
\hline Italy & 249.490 & 279.700 & 240.127 & 200.281 & 165.052 & 157.426 \\
\hline Spain & 67.534 & 58.255 & 51.318 & 45.924 & 45.233 & 54.406 \\
\hline Portugal & 15.340 & 23.080 & 23.129 & 25.563 & 33.084 & 38.812 \\
\hline Greece & 22.354 & 21.230 & 20.461 & 18.389 & 14.798 & 15.513 \\
\hline Poland & 18.370 & 7.642 & 4.871 & 7.760 & 43.085 & 61.524 \\
\hline Romania & n.d.a & n.d.a & n.d.a & 2.424 & 23.383 & 50.906 \\
\hline Bulgaria & n.d.a & n.d.a & n.d.a & 962 & 13.171 & 23.386 \\
\hline Turkey & 20.312 & 63.587 & 85.303 & 72.064 & 39.551 & 37.989 \\
\hline Morocco & 39.294 & 105.133 & 142.098 & 122.005 & 81.943 & 83.271 \\
\hline D. R. of Congo (Zaire) & 5.244 & 8.575 & 11.828 & 14.307 & 18.056 & 20.066 \\
\hline Others & 87.469 & 114.011 & 135.139 & 160.100 & 267.126 & 314.688 \\
\hline Total & 696.282 & 878.577 & 900.855 & 897.110 & 1.057 .666 & 1.195.122 \\
\hline
\end{tabular}

Sources: Directorate General of Statistics and Economic Information, Poulain and Perrin (2002). 
in the 2000s. In line with the decree on Flemish civic integration policy, ${ }^{3}$ since 2004, the government has implemented compulsory civic integration programmes for all new immigrants settling in Flanders. In contrast to Flanders, Francophones have been reluctant to recognise ethnic minorities (Jacobs 2004, 282). In Wallonia, the party system is characterised by the absence of extreme-right and nationalist parties as well as by a stronger preference of voters for centre-left parties. In this region, integration policies were originally limited and characterised by a laissez-faire policy in which local integration centres were in charge of developing their own integration programmes adapted to their local realities (Adam 2013, 554). Immigrant integration was mostly perceived as an inherent part of broader social policies focusing on the disadvantaged strata of the population. Accordingly, priority was given to the fight against social exclusion by prioritising education and positive discrimination measures.

Overall, by the eve of the 2008 financial and economic crisis, Belgium had already undergone dramatic transformations of its migration and integration policies, as dictated by institutional transformations and, most importantly, by electoral competition within

and between the two party systems. Yet, the overarching objective of limiting further immigration had not changed.

\subsection{Political and economic crises in Belgium since 2007}

Similarly to many other EU member states, Belgium was hit severely by the economic crisis. The peculiarity of Belgium, however, is that the economic crisis occurred during a period of acute political instability caused by a growing distrust between the Francophone and Flemish political parties.

A few months before the beginning of the economic crisis in Europe, Belgium experienced one of its longest political crises, as the country remained without a government for over 6 months following the 10 June 2007 federal elections. The main point of contention between the Flemish and Francophone political parties concerned the voting rights of Francophone minorities in Flemish municipalities around Brussels. As the parties eventually agreed to postpone debates on this issue until the next election, a new government was finally appointed in March 2008. The political crisis had, however, strongly affected the levels of trust between the parties and many observers predicted that its parliamentary majority would therefore be very fragile (Rihoux et al. 2011).

During the initial phase of the economic crisis in 2008, the recently appointed government was very rapidly put under significant pressure as three of Belgium's biggest banks (Fortis, Dexia and KBC) ran the risk of bankruptcy. In order to save these banks, the government invested about 20 billion euros in them (i.e. 5\% of the country's GDP). Moreover, the decision to nationalise Fortis Bank overnight had considerable political implications, as it raised major opposition among shareholders and triggered an investigation that led to the eventual resignation of Prime Minister Leterme in December 2008 (Troupin, Stroobants and Steen 2013, 5).

The appointment of a new prime minister coincided with the further deterioration of economic indicators. By 2009, Belgian public finances registered a deficit of $-5.6 \%$ of GDP and the public debt rose to $96.2 \%$ of GDP the same year. In addition, the economic crisis also affected seriously Belgium's labour market. Between 2008 and 2009, 20,000 jobs were destroyed (representing a net drop of 1.2\%). In light of those different indicators, it is not 
surprising that Belgium was considered - along with Portugal, Spain, Ireland, Greece and Italy - as one of the countries most at risk of falling into a long-lasting and profound economic recession in the early days of the economic crisis.

As shown in Figure 1, the deterioration in economic conditions had a differential impact on several categories of workers. For instance, the immigrant population seemed to be especially affected (Høj 2013), even though their level of unemployment was already higher than that of native workers prior to the economic crisis. In addition, as shown in Table 2, the level of support for immigration by nationals significantly eroded between the early hours of the economic crisis in 2008 and its peak in $2010 .{ }^{4}$ In other words, not only were immigrants in Belgium more affected by the crisis, nationals also increasingly questioned their social and economic 'added-value' as the effect of the recession became more visible.

The new government opted for several 'anti-crisis' policies, mainly consisting of measures facilitating access to temporary unemployment and specific reductions of the value-added-tax (VAT). After the dramatic setbacks of 2008 and 2009, Belgium began to gradually recover and by 2011, the labour market situation improved as unemployment reached its pre-crisis level.

The Federal legislative elections of 23 June 2010 initiated the second political crisis as electoral results confirmed the growing divide between Flemish and Francophone voters. In Flanders, the right-wing nationalist party (N-VA) became the largest party (29\%), while in Wallonia, the incumbent Socialist Party (PS) maintained its leadership. As these two parties had vowed not to govern together because of their irreconcilable positions on the future of Belgium as a unitary state and on decisions regarding the socio-economic reforms that ought to be implemented, a long period of political instability opened up. After 17 months (the longest period of government negotiation in history), the

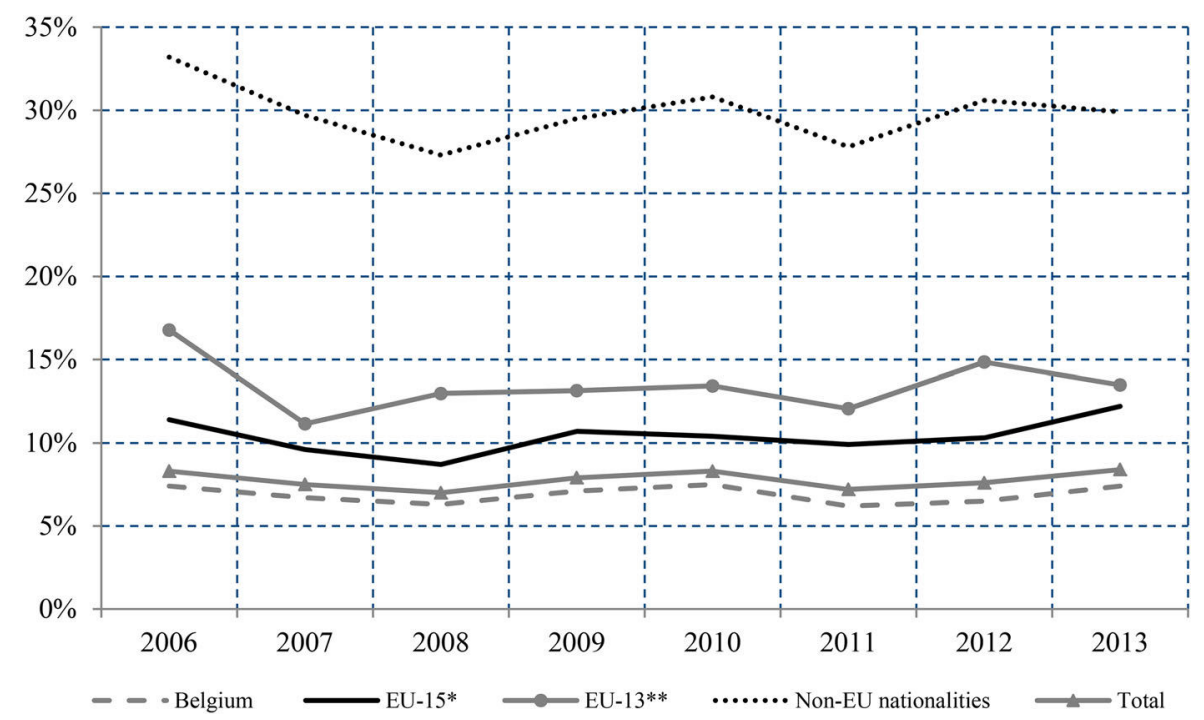

Figure 1. Evolution of unemployment rates in the EU by nationality 2006-2013. *EU member states prior to 2004 enlargement. ${ }^{* *} 2004,2007$ and 2013 accession member states. Source: EU Labour Force Survey 2005-2013. 
Table 2. Belgian nationals' attitudes towards immigrants 2006-2014. ${ }^{\mathrm{a}}$

\begin{tabular}{llllll}
\hline & 2006 & 2008 & 2010 & 2012 & 2014 \\
\hline Immigration bad or good for country's economy & 4.56 & 4.68 & 4.37 & 4.48 & 4.4 \\
Immigrants make country worse or better place to live & 4.58 & 4.8 & 4.55 & 4.66 & 4.69 \\
\hline
\end{tabular}

${ }^{a}$ Average scores on a scale from 0 (highly negative view on immigration) to 10 (highly positive view on immigration) Sources: European Social Survey-Waves 3, 4, 5, 6, 7.

French-speaking socialists managed to convince the Flemish parties to form a coalition government without the N-VA.

\subsection{Migration and integration policy reforms in times of crisis}

Starting in 2011, the combination of the long-lasting effect of the economic crisis and the perceived political instability of the country shared by most policy-makers has provided for an interesting context for the study of migration and integration policy reforms. On the one hand, an interest-based analysis of the reforms adopted in this period confirms the role of electoral competition in migration and integration policy-making: the political crisis strongly affected voters' confidence in the political parties and significantly increased political competition both within and between the two party systems. Indeed, the decision to govern without the country's largest party (N-VA) pushed other Flemish parties to support increasingly restrictive reforms at the Federal level in order to regain this share of the electorate. This position was in direct contradiction to the approach of another large member of the governing coalition - the Francophone PS - which had historically defended a more favourable stance on immigration.

On the other hand, an ideas-based approach to these reforms invites us to consider them as only a partial continuation of the past. Even though the objectives of national and regional immigration and integration policies are still very much in line with the restrictive approach that has prevailed since the 1970s (especially at the national and Flemish level), the context of economic crisis has led policy-makers to adjust existing policy instruments as well as to create new policy instruments in order to reach those same goals. In other words, the political crisis did not alter the goals of migration and integration policies but rather the means to achieve them.

\subsubsection{Policy objectives: continuing to keep undesirable migrants out}

In the last decade, Belgian migration law has been modified repeatedly at the initiative of the governing coalitions or in order to comply with EU directives. These reforms were passed with specific goals, such as combating the fraudulent misuse of the right to family reunion, combating forced marriage, and accelerating the asylum procedure and promoting the voluntary return of migrants (European Migration Network 2014). Important reforms implemented in this period, however, all share the overarching goal of making it harder for foreigners to come to Belgium when they are perceived to be 'non-economically productive' or 'undesirable'. By contrast, access for those that are highly skilled has been facilitated in Belgium and even encouraged. Indeed, the Belgian scheme for highly skilled migrants offers more favourable provisions than the so-called Blue Card Directive, ${ }^{5}$ that was transposed into Belgian law in $2012^{6}$ (Cerna 2013, 192).

In the field of family migration, the law on family reunification of 8 July 2011 introduced minimum income requirements for sponsors seeking family reunification in 
Belgium with family members residing abroad. The required level of income now has to be at least equivalent to $120 \%$ of the social integration income but this cannot come from social assistance (European Migration Network 2013). Even though it offered one of the few remaining options for migrating to Belgium, this reform was designed explicitly to make family reunification harder. In the words of MP Theo Francken (N-VA), it was meant to put an end to years of misuse of the 1980 Foreigners Law, epitomised by a 'laissez-faire and open-door approach' (La Chambre, Compte-rendu integral, 26 May 2011). On the Francophone side, MP Ducarme (Francophone Liberal Party, hereafter MR) confirmed that the governing coalition saw this reform as crucial to restore voters' confidence after the political crisis: 'the Belgian people needs to know that its Parliament is working even in the current context of crisis, in spite of which we have managed to pass this important reform' (La Chambre, Compte-rendu integral, 26 May 2011).

Reforms of family reunification procedures measures were accompanied by reforms on marriages and legal cohabitations of convenience in 2013 (European Migration Network 2014). ${ }^{7}$ In addition, information campaigns against forced marriage were conducted, targeting explicitly the Moroccan, Turkish, Algerian and Tunisian communities in Belgium.

With regards to labour migration, measures have also been taken to protect native workers in reaction to a fear of a large influx of EU workers following the enlargements to Central and Eastern Europe: Belgium extended transitional measures to restrict workers' access to the labour market until 31 December 2013 and later the Royal Decree of 24 June 2013 installed a transitory period regarding the free movement of Croatian workers until 30 June 2015 (European Migration Network 2013). In practice, this meant that workers arriving from those new EU countries had to apply for work permits in order to be able to work in Belgium.

Lastly, as mentioned above, Belgium transposed the EU return directive ${ }^{8}$ into Belgian law ${ }^{9}$ and modified its law on expulsion and detention (e.g. extending the deadline for leaving the territory from 5 to 30 days and encouraging the voluntary return of refused asylum seekers).

As demonstrated in this brief overview, the Belgian migration policy reforms of the past decade have exhibited a consistent trend of keeping undesirable migrants out of the country. However, this trend, in spite of the rhetorical arguments used during the debate, does not constitute a new focus in the objectives followed by migration policies since the 1970s. It is rather a deepening of existing restrictive policies already in place. This trend is consistent with the competition between and within the political systems in Belgium, characterised in the last decade by the growing influence of Flemish rightwing nationalists (the N-VA). Similar to the Vlaams Blok before, the consequence of the N-VA's electoral success was that migration and integration issues have remained publicly highly salient, forcing other Flemish parties to adopt a similar line to the N-VA on those issues.

\subsubsection{Adjusting existing policy instruments: towards a coercive approach to integration}

While the objectives of policy-makers seem to have remained unchanged with the economic and political crises of the past decades, policy instruments designed to reach these goals have been modified. This is most clearly visible with the reforms of integration policies at the Federal and Regional levels. These reforms support the objective of restricting 
further migration of non-economically active foreigners, but the instruments to achieve this (i.e. nationality law and integration courses) have taken a more coercive turn. Indeed, migrants who do not comply with integration goals that are set for them increasingly risk sanctions under the new legal provisions. In the implementation of these reforms, the desire to protect the Belgian welfare state from potential abusers makes a recurrent appearance. The crisis therefore offers policy-makers a unique opportunity to stress the idea that when public finances are under pressure, receiving country authorities can no longer justify access to welfare for all migrants, even when this population has been the most affected by the economic crisis.

The law of 4 December 2012, modifying the Belgian nationality code, represents the largest modification of citizenship rules in Belgium since the 1980s. It provided stricter conditions for accessing nationality and extended the minimum period of residence before applying for citizenship from 3 to 5 years. This represents a major shift compared to the last modification in 2000 , which was designed to facilitate access to nationality as a means to encourage integration. Contrarily to the previous legislation, the 2012 law contained a series of criteria designed to assess whether migrants are 'integrated enough' to be granted Belgian citizenship. Foreigners who have resided in Belgium for 5 years can apply for citizenship but must prove their knowledge of one of the three national languages. They must also demonstrate their social integration (e.g. with a school diploma, certificate of attendance of integration courses, etc.) and their economic integration (i.e. with evidence that they have worked for at least 468 days in the past 5 years). Similarly to the above-mentioned reforms, the tightening of conditions of access to Belgian citizenship has been justified by the fear of abuse and the necessity to protect the welfare state. These concerns were made particularly clear by the two largest Flemish parties of the governing coalition (Christen-Democratisch en Vlaams known as CD\&V and Open Vlaamse Liberalen en Democraten known as VLD) during parliamentary debates. Both parties insisted that abusers - defined as anyone who does not respect the economic criteria be barred from accessing Belgian citizenship (La Chambre, Compte-rendu intégral 26 May 2011).

Reforms of the regional integration policies in Wallonia and Flanders also epitomise the increasing use of conditionality and sanctions to force immigrants to adopt certain practices. In Flanders, where conditionality and sanctions had already been in place since the Inburgering reform of 2004 with the implementation of a compulsory civic integration programme for newcomers, the decree on the reform of the Flemish 'civic integration policy' of 21 December 2012, only confirmed this trend.

In Wallonia, by contrast, a major step was taken with the adoption of the 27 February 2014 decree on the Immigrant Integration Pathway which, for the first time, provides for some obligatory steps to be taken by newcomers arriving in Wallonia (i.e. meeting with a social worker and following a course on the rights and obligations of citizens in Belgium). The decree also provides for fines against immigrants refusing to participate in the initial steps of the Integration Pathway. The outcome of parliamentary debates on the Immigrant Integration Pathway was strongly determined by competition within Wallonia's party system. On the one hand, the PS was concerned to limit the obligatory and coercive nature of the scheme in order to protect its popularity among Belgian voters of foreign origin. To this end, it mostly used rhetorical arguments on Wallonia's 'tradition of welcoming foreigners' to justify the reform (Parlement wallon, Compte-rendu integral, 26 
March 2014). On the other hand, many within the Francophone Social-Democratic party called Centre Démocrate Humaniste $(\mathrm{CDH})$ - the coalition partner of the PS in the Walloon Region - were convinced that voters were expecting a tightening of integration policies in line with the reforms adopted at the Federal level. They were thus concerned that the Liberal Party (MR) would benefit electorally from legislation appearing too lax in the eyes of voters. Overall, the context of economic and political crisis appears therefore far less relevant than electoral competition in understanding Wallonia's mild shift to a more coercive approach to immigrant integration.

\subsubsection{New policy instruments: social policy as migration and integration policy}

Alongside the adjustments made to existing instruments, new policy instruments also arose with the policy reforms adopted in the context of economic and political crises. The main instrument has been social policy - and welfare in particular - which increasingly became a yardstick for determining whether individual migrants are economically valuable or not to the country. The first step in instrumentalising social policy to regulate migration has been the creation of the position of the State Secretary for Asylum, Migration and Social Integration, grouping those portfolios under the leadership of one single minister. Working with the new State Secretary Maggie De Block, the government has been able to develop a more comprehensive - but equally restrictive - approach towards the different legal and illegal avenues for migrating to Belgium. Most importantly, however, the inclusion of the social integration policy in her portfolio enabled the new State Secretary to use social policies as a means to regulate immigration.

The use of social policy for migration control arose in the context of budget cuts imposed during the economic crisis in order to meet budget deficit reduction plans. Public spending to support employment policies has been compensated for by cuts in other areas such as health care, education and pension schemes along with an imposed rise in taxation (Castanheira, Rihoux, and Bandelow 2014). In addition, more stringent controls and the supervision of welfare recipients have been introduced with the stated objective of reducing 'misuse and fraudulent access to benefits' (Nelson 2011).

Several restrictions and control measures have targeted the immigrant population and particularly EU citizens. Since 2012, newly arrived EU citizens have not been entitled to social benefits during the first 3 months of stay in Belgium. Also, EU citizens who are seeking work are not entitled to social benefits as long as they retain the status of job seeker (Mussche, Corluy, and Marx 2013). The most controversial measure was, however, implemented in 2011 and consisted of the large-scale withdrawal of residence permits from non-economically active EU citizens, who were claiming non-contributory social benefits in Belgium. This policy did not result from a new legal provision adopted in Parliament but rather from the restrictive interpretation made by the State Secretary for Asylum, Migration and Social Integration of the EU Directive 2004/38/EC on the right of citizens of the Union and their family members to move and reside freely within the territory of the member states. According to the directive, member states are allowed to withdraw the residence permit of EU citizens legally residing in the territory if they represent an 'unreasonable burden' on the public finances of the host state. In other words, this provision allows member states to expell undesirable EU migrants.

Citizens targeted by this measure are not the workers and self-employed but rather inactive EU citizens. These EU citizens, who had been granted residence permits in 
Belgium after they demonstrated that they had health coverage and sufficient resources to live autonomously, were expelled because - at some point after becoming official residents in Belgium - they received some form of welfare assistance. It is striking to note that the number of EU citizens expelled on this basis has exploded since 2011. That year, the Minister for Social Integration instigated the automatic exchange of information between the Social Security Administration and the Belgian Immigration Office. The consequence of this flow of information is visible in the sudden increase in the number of residence permits that were removed (Table 3).

As documented in the press, EU citizens who applied for a living allowance or asked for social assistance to deal with a specific difficulty (e.g. unexpected hospital or utility bills) were recurrently among those considered as a 'burden' and were accordingly targeted by this policy. Yet, the definition used by the administration to define an 'abusive use' of social assistance is extremely lax. For instance, EU citizens hired under specific activation schemes financed by the Social Security Administration to work in schools or hospitals were initially also expelled under this policy. The rationale was that publicly-financed jobs were not real jobs but rather a hidden form of social assistance. The legality of such an interpretation was nevertheless challenged (Mormont and Neven 2014). Most importantly, however, the European Commission itself expressed concerns over the sudden and dramatic increase in the removal of residence permits. It also reminded Belgium that it needed to pay more attention to the specific circumstances of each case, since expulsions should never be the automatic consequence of claiming benefits (European Commission 2014).

Targeting directly EU citizens is a major policy turn in Belgian politics. Indeed, such a stance against the freedom of circulation of EU citizens damages the country's image as an advocate of a deeper EU integration process. Heightened political competition following the political crisis, however, explains why political parties are willing to take such a risk. Similarly to other reforms, competition within the Flemish party system pushed the two Flemish coalition partners at the Federal level (VLD and CD\&V) to appear tough on the issue of migration in order to appeal to N-VA voters.

The economic crisis provided those parties with a unique opportunity to frame those reforms as indispensable in the context of decreasing resources for social programmes. For the State Secretary, 'undeserving EU migrants' represent a threat to Belgium's welfare system and her policies were designed 'to avoid immigrants being here only to take advantage of the social system' (RTL info 2013). She received significant support in implementing this policy, including from the Flemish coalition partner of the Christian Democrats $(C D \& V)$, who considered that Belgium should not become 'Europe's welfare

Table 3. Number of residence permits removed by nationality on the basis of directive 2004/38/EC.

\begin{tabular}{cccccccccccc}
\hline & & \multicolumn{1}{c}{ The } & & & & & & \multicolumn{2}{c}{$\begin{array}{c}\text { Change in } \\
\%\end{array}$} \\
\hline 2008 & Spain & Italy & Netherlands & France & Romania & Slovakia & Poland & Bulgaria & Other & Total & n \\
2009 & n/a & n/a & n/a & n/a & n/a & n/a & n/a & n/a & n/a & 8 & - \\
2010 & 75 & 5 & 60 & 21 & 43 & 91 & 11 & 31 & 6 & 343 & +462.3 \\
2011 & 98 & 28 & 102 & 32 & 96 & 108 & n/a & 261 & 817 & 1542 & +349.6 \\
2012 & 207 & 75 & 161 & 109 & 402 & 73 & 70 & 236 & 585 & 1918 & +24.4 \\
2013 & 323 & 265 & 305 & 176 & 816 & 60 & 66 & 393 & 308 & 2712 & +41.4 \\
\hline
\end{tabular}

Source: Office des Etrangers (2008, 2009, 2010, 2011, 2012, 2013). 
agency' (Het Nieuwsblad, 5 June 2013). But support also came from the Flemish nationalist opposition party N-VA, who denounced the cost of welfare for EU citizens as 'unbearable in times of economic crisis' (La Chambre, Compte-rendu integral, 23 October 2012).

Overall, while the policy of expelling non-economically active EU citizens constitutes a new instrument within Belgium's migration policy, its objective is fully consistent with the long-term goal of keeping undesirable migrants out.

\section{Migration policy reforms in times of crisis: conclusive lessons from Belgium}

At the outset of this article we argued that - while crises are often described as stimuli for migration policy reforms - little is still known about the extent to which they affect migration and integration policies, about the mechanisms that lead to specific policy reactions or about the interaction with other variables that may equally affect policy-making during crises. Drawing on the case of Belgium, which experienced two crises in combination over the same period of time, we therefore wish to conclude this article by stressing the importance of combining interest-based and ideas-based approaches to migration and integration policy-making.

Because of its focus on electoral competition, the interest-based approach has been useful in our analysis in determining whether crises are serious enough to change a party's perception of the salience of migration issues for voters. In the case of Belgium, we have shown that crises only served to reinforce that perception. Moreover, this approach did not allow us to determine the exact impact of crises on policies. However, the ideas-based approach we presented did offer an interesting complement in this regard. It prompted us to disaggregate policy-making in times of crisis as processes that can lead to three types of change: changes in policy goals, adjustments within existing policy instruments to reach these goals, and the adoption of new instruments. With the Belgian case study, we showed that electoral competition remained a central variable in migration and integration policy-making processes but that crises triggered adjustments to policy instruments and the adoption of new policy instruments.

\subsection{Crises and policy objectives}

As disruptive and challenging as they were, the political and economic crises that affected Belgium did not dramatically change the goals of the country's migration and integration policies. Since the 1970s, Belgium has developed policies whose objectives were to keep economically inactive migrants out, and those objectives have been maintained and reaffirmed throughout the crises.

The absence of alterations to policy objectives has been justified by the fact that the crises did not profoundly alter the state of electoral competition in Belgium. The presence of a strong xenophobic party in Flanders in the 1990s (Vlaams Belang) and the emergence of a strong right-wing nationalist party in the 2000s (N-VA) have maintained the high saliency of migration issues in the public throughout the crises. Electoral competition within Flanders therefore dictated that Region's stricter stance on integration. Yet, it also explained the importance for Flemish parties of imposing their views on migration and 
integration policies at the national level where, historically, they have had to find a compromise with the Francophone parties (which traditionally lean towards the centre left).

This is not to say, however, that crises have no effect on policy objectives in the field of migration and integration. Political crises, in particular, create a sense of political emergency that increases electoral competition. It also forces parties to act in policy areas where they believe they can gain credit among voters. Within the context of a political crisis, policy-makers therefore perceive that the electoral cost of inaction or failure is substantially higher than in a non-crisis environment. The specificity of large-scale political crises such as Belgium's - in which the political class has become entirely discredited is that policy-makers are unable to blame external factors. The choice of policy areas in which reforms are likely to be received positively by the majority of voters therefore becomes of critical importance in restoring confidence. Migration and integration are very appropriate policy areas to focus on for two reasons. First, they affect primarily foreigners who usually have no or limited voting rights. Second, reforms in this area touch upon fundamental prerogatives of the state: for example, Who is a citizen? Who has access to the territory? Who is entitled to receive welfare? It is therefore a privileged policy area for policy-makers, where appearing firm and in control is likely to reaffirm the authority of the state in the eyes of citizens; especially when support for immigration had declined with the economic crisis. In the case of Belgium, this has meant explicitly maintaining and even reinforcing the objective that has been in place for over 30 years - that of keeping undesirable migrants out.

\subsection{Crises and policy instruments}

While the political crisis explained the urge to act in the area of migration and integration and the importance for political parties to appear to be adopting strict policies, it did not offer a satisfactory explanation for the choice of policy instruments to be adopted or reformed in order to reach this objective. Examining those precise changes, however, allowed us to distinguish the effects of the political crisis from those of the economic crisis.

The case of Belgium shows that numerous existing policy instruments have been reformed and that a selected number of new policies have been adopted in the dual context of economic and political crises. Existing policies, particularly in the field of integration, have been modified to include or strengthen coercive measures and sanctions (e.g. the nationality law and regional integration policies). New policy instruments, on the other hand, are characterised by the instrumentalisation of social policy, and welfare in particular, to serve the objectives of migration and integration policies.

The economic crisis and associated budget cuts to welfare programmes adopted in Belgium (and throughout Europe) have allowed political parties to develop a discourse about the 'threatened European welfare state'. Rhetorical arguments about the survival of the welfare state have served to reform social policies but also migration and integration policies. In both cases, reforms have been generally characterised by a decrease in accessibility and an increase in sanctions faced by individuals deemed undeserving of social assistance. Most importantly, however, such a discourse has legitimised the use of welfare policies as instruments for migration control, and more precisely, to keep undesirable migrants out. While this process had been observed in other national contexts before, the case of Belgium has, however, demonstrated that the economic crisis provided political 
parties with a powerful narrative to implement restrictions on immigrants' access to welfare under the guise of protecting the welfare state. This, in turn, strongly differentiated the effects of the economic crisis from those of the political crisis in the case of Belgium.

Overall, this article has stressed the peculiar situation of Belgium as a federal state under economic and political tension. Further comparative work with other federal states and more centralised states, as well as the study of Southern European states more deeply affected by contexts of multiple crises, would undoubtedly deepen our understanding of migration policy reforms in times of crisis. Indeed, states like Greece or Spain have been confronted to various crises (economic, political, humanitarian) which develop at different levels of governance. More recently, several other EU Member States have also had to deal with combined political and humanitarian crises following the increase in flows of asylum seekers in 2015. Nevertheless, our study of the continuities and transformations of recent migration and integration policies offers three key lessons. First, combining interest-based and ideas-based approaches to migration and integration policy-making helps disentangle the effects of crisis from those of broader and longer-term variables such as electoral competition. Second, it is crucial to look both at the objectives and policy instruments in the migration and integration policy-making process in order to be able to determine what type of change or continuities are triggered by crises. Third, economic and political crises have differentiated effects, and their interaction, as shown in Belgium, creates stronger pressure for the reform of migration and integration policy instruments. In other words, the effects of the economic and political crises are not only differentiated, they are also cumulative.

\section{Notes}

1. In Brussels, competition between the Flemish and Francophone parties is partly possible but because of the demographic structure of the region, the Francophone parties continue to win an overwhelming majority of the votes.

2. Décret relatif à l'intégration des personnes étrangères ou d'origine étrangère adopted by the Walloon Government on 4 July 1996. Decreet Etnisch-culturele minderheden adopted by the Flemish Government on 28 April 1998.

3. Decreet van 28 februari 2003 betreffende het Vlaams inburgeringsbeleid.

4. Decrease in support for immigration was equally observed in Flanders, Wallonia and Brussels between 2008 and 2010.

5. Council Directive 2009/50/EC of 25 May 2009 on the conditions of entry and residence of third-country nationals for the purposes of highly qualified employment.

6. Law of 15 May 2012 and Royal Decrees of 15 August 2012, 17 July 2012 and 3 August 2012.

7. The law of 2 June 2013 provided a legal definition of legal cohabitation of convenience and in November 2013, another measure making information regarding marriages and legal cohabitations of convenience accessible via the National Register was approved (European Migration Network 2014).

8. Directive 2008/115/EC of the European Parliament and of the Council of 16 December 2008 on common standards and procedures for returning illegally staying third-country nationals.

9. Law of 19 January 2012 amending the Aliens Law (Belgian Official Journal of 17 February 2012). This law came into force on 27 February 2012.

\section{Disclosure statement}

No potential conflict of interest was reported by the authors. 


\section{References}

Adam, I. 2013. "Immigrant Integration Policies of the Belgian Regions: Sub-state Nationalism and Policy Divergence after Devolution.” Regional \& Federal Studies 23 (5): 547-569. doi:10.1080/ 13597566.2013.789024.

Adam, I., and C. Torrekens. 2015. "Different Regional Approaches to Immigration Related Cultural Diversity. Interpreting the Belgian Cultural Diversity Policy Paradox." Régionalimse et Fédéralisme (online only). http://popups.ulg.ac.be/1374-3864/index.php?id=1526.

Alink, F., A. Boin, and P. T'Hart. 2001. "Institutional Crises and Reforms in Policy Sectors: The Case of Asylum Policy in Europe." Journal of European Public Policy 8 (2): 286-306. doi:10. 1080/13501760151146487.

Boswell, C. 2007. “Theorizing Migration Policy: Is There a Third Way?” International Migration Review 41 (1): 75-100. doi:10.1111/j.1747-7379.2007.00057.x.

Bousetta, H., S. Gsir, and D. Jacobs. 2007. "Belgium.” In European Immigration: A Sourcebook, edited by A. Triandafyllidou and R. Gropas, 33-44. Aldershot: Ashgate.

Castanheira, M., B. Rihoux, and N. C. Bandelow. 2014. Belgium Report. Sustainable Governance Indicators 2014 Project. Gütersloh: Bertelsmann Stiftung. http://www.sgi-network.org/docs/ 2014/country/SGI2014_Belgium.pdf.

Cerna, L. 2010. Policies and Practices of Highly Skilled Migration in Times of the Economic Crisis. International Migration Papers 99. Geneva: International Labor Organization. http://www.ilo. org/wcmsp5/groups/public/—ed_protect/—protrav/—migrant/documents/publication/wcms_ 179666.pdf.

Cerna, L. 2013. "Understanding the Diversity of EU Migration Policy in Practice: The Implementation of the Blue Card Initiative." Policy Studies 34 (2): 180-200. doi:10.1080/ 01442872.2013.767587.

Coffé, H. 2005. "Do Individual Factors Explain the Different Success of the Two Belgian Extreme Right Parties." Acta Politica 40 (1): 74-93. doi:10.1057/palgrave.ap.5500078.

European Commission. 2014. Libre circulation: la Commission demande à la Belgique de respecter les règles de l'UE. Brussels: European Commission.

European Migration Network. 2013. Annual Report on Asylum and Migration Policy in Belgium 2012. Brussels: EMN-Belgian Contact Point. http://ec.europa.eu/dgs/home-affairs/what-we-do/ networks/european_migration_network/reports/docs/annual-policy/2012/be_emn_policy_ report_2012_-_final_en.pdf.

European Migration Network. 2014. Annual Report on Asylum and Migration Policy in Belgium 2013. Brussels: EMN-Belgian Contact Point. http://www.emnbelgium.be/sites/default/files/ publications/be_policy_report_2013_on_migration_and_asylum_emn_0.pdf

Freeman, G. 1995. "Modes of Immigration Politics in Liberal Democratic States." International Migration Review 29 (4): 881-902. doi:10.2307/2547729.

George, A., and A. Bennett. 2005. Case Studies and Theory Development in the Social Sciences. Cambridge: MIT Press.

Hall, P. A. 1993. "Policy Paradigms, Social Learning, and the State: The Case of Economic Policymaking in Britain." Comparative Politics 25 (3): 275-296. doi:10.2307/422246.

Hall, P. A., and R. Taylor. 1996. "Political Science and the Three New Institutionalisms." Political Studies 44: 936-957. doi:10.1111/j.1467-9248.1996.tb00343.

Høj, J. 2013. Enhancing the Inclusiveness of the Labour Market in Belgium. OECD Economic Department Working Paper (2013)1. Paris: OECD. http://www.oecd.org/eco/labour/2013-1.pdf.

Hollifield, J. 2000. "The Politics of International Migration. How can we 'Bring the State back in'?" In Migration Theory: Talking Across Disciplines, edited by C. Brettel and J. Hollifield, 137-185. London: Routledge.

Jacobs, D. 1999. “The Debate Over Enfranchisement of Foreign Residents in Belgium.” Journal of Ethnic \& Migration Studies 25 (4): 649-663. doi:10.1080/1369183X.1999.9976708.

Jacobs, D. 2004. "Alive and Kicking? Multiculturalism in Flanders." International Journal on Multicultural Societies 6 (2): 280-299. 
Joppke, C. 1998. “Why Liberal States Accept Unwanted Migration.” World Politics 50 (2): 266-293. doi:10.1017/S004388710000811X.

Koopmans, R., I. Michalowski, and S. Waibel. 2012. "Citizenship Rights for Immigrants: National Political Processes and Cross-National Convergence in Western Europe, 1980-2008.” American Journal of Sociology 117 (4): 1202-1245. doi:10.1086/662707.

Kuptsch, Ch. 2012. "The Economic Crisis and Labour Migration Policy in European Countries." Comparative Population Studies 37 (1-2): 15-32. doi:10.4232/10.CPoS-2011-17en.

Legro, J. 2000. “The Transformation of Policy Ideas." American Journal of Political Science 44 (3): 419-432. doi:10.2307/2669256.

Martiniello, M., A. Rea, C. Timmerman, and J. Wets, eds. 2010. Nouvelles migrations et nouveaux migrants en Belgique. Gent: Academia Press and Politique Scientifique Fédérale.

Massey, D. 1999. "International Migration at the Dawn of the Twenty-First Century: The Role of the State." Political and Development Review 25 (2): 303-322. doi:10.1111/j.1728-4457.1999. 00303.x.

Money, J. 1999. Fences and Neighbors: The Political Geography of Immigration Control in Advanced Market Economy Countries. Ithaca, NY: Cornell University Press.

Mormont, H., and J.-F. Neven. 2014. "Le droit à l'aide sociale et le droit à l'intégration sociale en faveur des étrangers: questions d'actualité." In Questions spéciales de droit social Hommage à Michel Dumont, edited by J. Clesse and J. Hubin, 13-172. Bruxelles: Larcier.

Muller, P., and Y. Surel. 1998. L'analyse des politiques publiques. Paris: Montchrestien.

Mussche, N., V. Corluy, and I. Marx. 2013. "Migrant Access to Social Security - Policy and Practice in Belgium." Study for the Belgian National Contact Point of the European Migration Network. Brussels: European Commission. http://www.emnbelgium.be/publication/migrant-access-socialsecurity-policy-and-practice-belgium-and-eu-emn.

Nelson, K. 2011. Improving the Efficiency of Social Protection. Brussels: European Commission. http://ec.europa.eu/social/images/icons/pdf.gif

Nohrsted, D., and Ch. M. Weible. 2010. "The Logic of Policy Change after Crisis: Proximity and Subsystem Interaction.” Risk, Hazards, \& Crisis in Public Policy 1 (2): 1-32. doi:10.2202/19444079.1035.

Obinger, H., P. Starke, J. Moser, C. Bogedan, E. Gindulis, and S. Leibfried. 2010. Transformations of the Welfare State: Small States, Big Lessons. Oxford: Oxford University Press.

Office des Etrangers. 2008. Rapports d'activités 2008. Bruxelles: SPF Intérieur.

Office des Etrangers. 2009. Rapports d'activités 2009. Bruxelles: SPF Intérieur.

Office des Etrangers. 2010. Rapports d'activités 2010. Bruxelles: SPF Intérieur.

Office des Etrangers. 2011. Rapports d'activités 2011. Bruxelles: SPF Intérieur.

Office des Etrangers. 2012. Rapports d'activités 2012. Bruxelles: SPF Intérieur.

Office des Etrangers. 2013. Rapports d'activités 2013. Bruxelles: SPF Intérieur.

Papademetriou, D., M. Sumption, and W. Somerville. 2009. Migration and the Economic Downturn: What to Expect in the European Union. Migration Policy Institute Working Paper. Washington, DC: Migration Policy Institute. http://www.migrationpolicy.org/research/migration-andeconomic-downturn-what-expect-european-union.

Papademetriou, D., and A. Terrazas. 2009. Immigrants and the Current Economic Crisis: Research Evidence, Policy Challenges, and Implications. Migration Policy Institute Working Paper. Washington, DC: Migration Policy Institute. http://www.migrationpolicy.org/pubs/lmi_ recessionJan09.pdf.

Poulain, M., and N. Perrin. 2002. "The Demographic Characteristics of Immigrant Populations in Belgium.” In The Demographic Characteristics of Immigrant Populations, edited by W. Haug, P. Compton, and Y. Courbage, 57-130. Strasbourg: Council of Europe Publishing.

Rea, A. 2006. "Les politiques d'immigration: des migrations ordonnées aux migrations débridées." In Penser l'Immigration autrement. Une initiative belge inter-universitaire, edited by B. Khader, M. Martiniello, A. Rea, and C. Timmerman, 177-207. Bruxelles: Bruylant.

Rihoux, B., P. Dumont, L. De Winter, S. Deruette, and D. Bol. 2011. "Belgium.” European Journal of Political Research 50 (7-8): 913-921. doi:10.1111/j.1475-6765.2011.02013.x. 
RTL Info. 2013. Maggie De Block: 'Il faut éviter que des gens profitent de notre système social'. Brussels: RLT. http://www.rtl.be/info/belgique/politique/maggie-de-block-il-faut-eviter-quedes-gens-profitent-de-notre-systeme-social-video-396658.aspx

Troupin, S., J. Stroobants, and S. Trui. 2013. "The Impact of the Fiscal Crisis on Belgian Federal Government: Changes in the Budget Decision Making Process and Intra-governmental Relations." Paper presented at the Conference on the Impact of the financial crisis on public administration, Tallinn, May 3-4.

Watts, J. 2002. Immigration Policy and the Challenge of Globalization. Unions and Employers in Unlikely Alliance. Ithaca, NY: ILR Press, an imprint of Cornell University Press. 